Jurnal IImiah : Biologi Eksperimen dan Keanekaragaman Hayati

Vol. 2 No. 2 November 2014 : hal. $86-90$

ISSN : 2338-4344

\title{
UJI KOGNITIF MENCIT (Mus musculus L.) JANTAN BERBEDA UMUR YANG DIBERI EKSTRAK LADA HITAM (Piper nigrum L.)
}

\section{Cognitive Test MaleMouse (Mus musculus L.) Of Different Ages Were Given Black Pepper (Piper nigrum L.)Extract}

\author{
Monica Sapitri, M. Kanedi, Hendri Busman, Sutyarso \\ Jurusan Biologi FMIPA Universitas Lampung \\ E-mail : monicasapitri@yahoo.co.id \\ Jurusan Biologi FMIPA, Universitas Lampung \\ Jl. Prof.Dr. Soemantri Brojonegoro No. 1, Bandarlampung, Lampung, Indonesia, 35145
}

\begin{abstract}
Abstrak
Lada hitam adalah salah satu jenis rempah yang diketahui mengandung antioksidan. Antioksidan adalah zat yang dipercayadapat menghambat proses penuaan. Penuaan ditandai dengan menurunnya berbagai fungsi organ tubuh, termasuk otak sehingga berdampak pada menurunnya daya ingat. Penelitian ini bertujuan mengetahui pengaruh pemberian ekstrak lada hitam terhadap daya ingat mencit (Mus musculus L.).Empat puluh ekor mencit jantan, masing-masing 20 ekor berumur 4 bulan (muda) dan 20 ekor berumur 6 bulan (tua), diberi empat perlakuan yaitu : tanpa ekstrak sebagai kontrol (K), ekstrak air (A), ekstrak etanol (E), dan ekstrak campuran air-etanol (C). Data dianalisis menggunakan Sidik Ragam 2 Jalur (Two Ways ANOVA). Hasil penelitian menunjukkan bahwa mencit tua lebih cepat mengingat jalur dalam uji labirin, tetapi cendrung tidak berbeda dengan mencit muda dalam mengingat balok pijakan pada uji renang. Melalui uji labirin, daya ingat mencit muda dan tua yang diberi ekstrak lada hitam terbukti lebih baik dari pada yang tidak diberi. Sedangkan dalam uji renang, daya ingat mencit muda lebih baik pada yang diberi ekstrak air, sedangkan pada mencit tua hanya ekstrak campuran yang bisa membuat daya ingat lebih baik.
\end{abstract}

Kata kunci: antioksidan, mencit (Mus musculus L.), lada hitam (Piper nigrum L.).

\begin{abstract}
Black pepper (Piper nigrum L.) is one of the herbs that are known to contain antioxidants. Antioxidants are substances that are believeduseful toinhibit aging. Aging is characterized by decrease in the various capability of the body organs, includingbrain so thatdecrease in memory. Research aims to know the influence of black pepper extract against memory of mice (Mus musculus L.). Forty male mice, divided into two groups, i.e. 20 of young male (4 months) and 20 of old-ones (6 months), are given four treatments, namely :no-extract as control (K), water extract (A), ethanol extract $(E)$, and the water-ethanol extract mixtures (C). Data were analyzed using Two Ways ANOVA. The results showed that old mice are quicker in recalling line in the maze test, but was not different with the young mice in recalling a given beam footing on a swimming test. Through a maze test it was revealed that both young and old mice treated with black pepper extract have a better memory than that of untreated ones. Meanwhile, trough swimming test the results proved that only young male treated with water extract and the-old ones treatred with water-ethanol mixtures showed better memory.
\end{abstract}

Keywords : antioxidants, mouse (Mus musculus L.), black pepper (Piper nigrum L.).

\section{PENDAHULUAN}

Salah satu komoditas rempah penting yang dihasilkan di Indonesia yaitu lada hitam (Majeed \& Prakash, 2000).Kandungan kimia lada hitam terdiri dari beberapa bahan aktif seperti phenolic amides, phenolic acids, dan flavonoid yang bersifat antioksidan(Meghwal \& Goswami, 2012).

Antioksidan mampu melindungi tubuh dari kerusakan yang disebabkan oleh oksigen reaktif.Penggunaan senyawa antioksidan juga sebagai anti radikal bebas yang saat ini semakin meluas seiring dengan semakin 
besarnya pemahaman masyarakat tentang peranannya dalam menghambat penyakit degeneratif seperti penyakit jantung, arteriosclerosis, kanker, serta gejala penuaan (Tahir dkk, 2003).Antioksidan digunakan untuk memperkecil terjadinya prosesoksidasi dari lemak dan minyak, memperkecil terjadinya proses kerusakan dalam makanan, memperpanjang masa pemakaian dalam industri makanan, meningkatkan stabilitas lemak yang terkandung dalam makanan serta mencegah hilangnya kualitas sensori dan nutrisi (Hernani dan Raharjo, 2005).

Menurut Singh et al (2008) dalam uji antioksidan yang dilakukan terhadap ekstrak petroleum ether lada hitam secara in vitro berhasil membuktikan bahwa ekstrak lada hitam efektif menghambat beberapa radikal bebas. Melihat berbagai kandungan zat yang terdapat dalam lada hitam yaitu salah satunya sebagai sumber antioksidan maka perlu dilakukan penelitian mengenai pengaruh penambahan ekstrak lada hitam pada pakan. Hewan uji yang digunakan yaitu mencit dengan memberikan penambahan ekstrak lada hitam pada pakan mencit. Mencit yang digunakan diamati perilaku kognitfnya yang meliputi daya ingat belajar labirin dan daya ingat renang setelah diberikan penambahan ekstrak lada hitam pada pakan yang merupakan salah satu perubahan fungsi yang akan ditunjukkan pada proses penuaan suatu organisme.

Kognitif adalah kemampuan berpikir dan memberikan rasional, termasuk proses belajar, mengingat, menilai, orientasi, persepsi dan memperhatikan. Gangguan fungsi kognitif erat kaitannya dengan fungsi otak karena kemampuan untuk berpikir akan dipengaruhi oleh otak.

Ivey (1993),mengatakan bahwa perilaku kognitif didasarkan pada asumsi bahwa perilaku manusia secara langsung dipengaruhi oleh pemikiran, perasaan, proses fisiologis, serta pada perilaku. Jadi bila ingin mengubah perilaku dari manusia, maka tidak hanya sekedar mengubah perilakunya saja, namun juga menyangkut aspek kognitifnya.

Secara fisiologi ingatan merupakan hasil dari perubahan kemampuan penjalaran sinaptik dari suatu neuron ke neuron berikutnya.Ingatan dibagi menjadi tiga yaitu ingatan jangka panjang, ingatan jangka pendek, dan ingatan jangka menengah. Faktor yang menyebabkan menurunnya ingatan antara lain kurang tidur, tekanan darah tinggi, terlalu banyak mengkonsumsi alkohol, stres kronis, dan kerusakan dalam hubungan sel saraf otak. Dalam proses belajar juga sangat penting sebab, dengan dengan belajar maka semua sel-sel otak akan ikut aktif sehingga proses memori menjadi lebih mudah mengingat (Venustri, 2006).

Penelitian ini bertujuan untuk mengetahui pengaruh pemberian ekstrak lada hitam terhadap daya ingat mencit (Mus musculus L.) jantan.

\section{BAHAN dan METODE}

\section{Pembuatan ekstrak lada hitam dan peracik- an pakan}

Lada yang digunakan merupakan lada hitam yang diperoleh dari petani buah lada di provinsi Lampung.Lada dipilih yang bernas Ialu dikeringkan.Kemudian lada hitam diekstraksi dengan metode maserasi menggunakan dua macam pelarut, yaitu etanol dan air.

Masing-masing ekstrak kemudian ditambahkan pada pakan mencit dengan komposisi $0,3 \mathrm{~g}$ dalam setiap $1 \mathrm{~kg}$ pakan lalu dicetak kembali. Pakan dicetak membentuk batangan dengan panjang 4-5 cm dan diameter 0,5-1 cm, kemudian dikeringkan. Pakan inilah yang akan diberikan pada mencit hewan uji selama 3 bulan. Setelah 3 bulan perlakuan mencit yang berumur 4 bulan dan 6 bulan, mencit tersebut akan berumur 7 bulan dan 9 bulan.

\section{Pemeliharaan dan perlakuan ekstrak}

Mencit dipelihara dalam kandang berupa bak plastik yang diberi tutup kawat dengan ukuran $20 \times 40 \mathrm{~cm}$. Dasar kandang diberi serbuk kayu dan dalam satu kandang dipelihara 5 ekor mencit. Selama pemeliharaan, mencit diberi pakan berupa pelet pakan ayam dicampur tepung jagung dan tepung terigu yang dicetak ulang berbentuk batang dengan diameter sekitar $1 \mathrm{~cm}$ sebagai langkah habituasi 1 bulan dengan pemberian pakan sebelum perlakuan menggunakan ekstrak lada hitam selama 3 bulan dan diberi minum dalam botol minum khusus mencit.

Mencit yang digunakan 20 ekor mencit muda dan 20 ekor mencit tua. Masing-masing mencit diberi 4 perlakuan ekstrak. Pola pengelompokkan perlakuan yang dipakai adalah sebagai berikut:

1. KO adalah kelompok mencit yang tidak diberi ekstrakdengan pakan pelet yang dicetak ulang dalam bentuk batang berdiameter 0,5-1,0 cm dan memiliki berat 4-5 g.

2. K1 adalah kelompok mencit yang diberi ekstrak air dengan pakan pelet yang dicetak $\mathrm{u}$ lang dalam bentuk batang berdiameter $0,5-$ $1,0 \mathrm{~cm}$ dan memiliki berat $4-5 \mathrm{~g}$.

3. K2 adalah kelompok mencit yang diberi ekstrak etanol dengan pakan pelet yang dicetak ulang dalam bentuk batang berdiameter 0,5 $1,0 \mathrm{~cm}$ yang memiliki berat $4-5 \mathrm{~g}$. 
4. K3 adalah kelompok mencit yang diberi ekstrak campuran (air dan etanol) dengan pakan pelet dalam bentuk batang berdiameter $0,5-1,0 \mathrm{~cm}$ yang memiliki berat $4-5 \mathrm{~g}$.

\section{Parameter yang diamati}

Parameter yang diamati dalam penelitian ini adalah kecepatan daya ingat mencit setelah diberi ekstrak lada hitam pada masing-masing perlakuan. Parameter pertama yang diamati yaitu dengan menggunakan labirin dengan luas $100 \times 100 \mathrm{~cm}$, labirin merupakan jalur/jalan yang rumit, berliku-liku serta memiliki jalan yang buntu, dimana mencit di masukkan ke dalam labirin sebagai proses belajar, kemudian menghitung waktu yang dibutuhkan mencit untuk keluar dari labirin. Setelah selesai labirin di semprot dengan alkohol untuk menghapus jejak mencit dan dibiarkan beberapa saat sampai kering, dan parameter kedua menggunakan daya ingat (renang) yaitu dengan menggunakan bak besar berdiameter $50 \mathrm{~cm}$, dan berisi air dimana di dalam bak yang berisi air di letakkan balok dengan ukuran $15 \times 15 \mathrm{~cm}$ di ujung sebagai pijakan mencit yang telah diberi tanda garis berwarna putih sebagai akhir dari uji pengamatan yang diamati dengan panjang $35 \mathrm{~cm}$ dari awal mencit dilepaskan ke dalam bak sampai mencit berhenti di balok pijakan, dan mencatat waktu (detik) tempuh mencit tersebut dengan menggunakan stopwatch dan kamera pada setiap perlakuan yang akan diuji dengan pengulangan sebanyak 5 kali.

\section{Analisis data}

Data yang diperoleh dari hasil perlakuan mencit uji kognitif labirin dan renang akan dianalisis secara deskriptif dan dengan menggunakan Analisis Ragam (ANARA) 2 jalur. Jika ada perbedaan yang nyata maka akan dilakukan uji lanjut dengan menggunakan Uji Beda Nyata Terkecil (BNT) pada taraf 5\% untuk mengetahui perbandingan dari masing-masing kelompok.

\section{HASIL dan PEMBAHASAN}

1. Uji Labirin Mencit.

Hasil uji perbandingan rata-rata waktu (detik) tempuhuji mencit, antara mencit umur 7 bulan dan mencit umur 9 bulan disajikan dalam (Tabel 1).

Pada perbandingan antara kelompok umur 7 bulan dan 9 bulan terdapat perbedaan yang nyata antara rata-rata waktu (detik) labirin mencit umur 7 bulan dan umur 9 bulan pada kelompok kontrol dan kelompok perlakuan pada penambahan ekstrak air , etanol dan ekstrak campuran (air dan etanol) lada hitam. Fungsi belajar dinilai dari waktu yang digunakan pertama kali mengenali lingkungan disekitar labirin maupun renang, waktu retensi yang menggambarkan fungsi kognitif penyimpanan memori dinilai dengan respon sewaktu dilakukan uji ulangan dengan kondisi yang sama dan secara pasif membiarkan subjek menentukan dan memutuskan sendiri sesuai dengan fungsi kognitifnya. Lama retensi adalah waktu retensi pada perlakuan pengulangan mencit.Rata-rata lama retensi waktu (detik) kontrol mencit umur 7 bulan mencapai 288detik, dan pada mencit umur 9 bulan lama retensi menurun dengan lama rata-rata retensi 151 detik.

Tabel 1. Perbandingan rata-rata waktu (detik) tempuh uji labirin mencit jantan antara kelompok umur 7 dan 9 bulan.

\begin{tabular}{cccc}
\hline \multirow{2}{*}{ No } & \multirow{2}{*}{ Perlakuan } & \multicolumn{2}{c}{ Waktu (detik) \pm SD } \\
\cline { 2 - 4 } & & 7 bulan & 9 bulan \\
\hline 1 & $\mathrm{~K}$ & $288 \pm 88,24 \mathrm{a}$ & $151 \pm 100,36 \mathrm{c}$ \\
2 & $\mathrm{C}$ & $133 \pm 62,90 \mathrm{ab}$ & $83 \pm 68,42 \mathrm{~cd}$ \\
3 & $\mathrm{E}$ & $53 \pm 24,39 \mathrm{~b}$ & $71 \pm 17,66 \mathrm{~d}$ \\
4 & $\mathrm{~A}$ & $36 \pm 23,07 \mathrm{~b}$ & $38 \pm 19,40 \mathrm{~d}$ \\
\hline Keterangan : Nilai yang diikuti pada huruf yang sama tidak \\
berbeda nyata pada uji BNT dengan taraf \\
signifikans 5\%; (K) Kontrol, (C) Ekstrak \\
Campuran (Air dan Etanol), (E) Ekstrak \\
Etanol, dan (A) Ekstrak Air.
\end{tabular}

Pada penambahan ekstrak air, etanol dan campuran lada hitam tidak terlihat beda nyata. Karena, pada kelompok mencit umur 7 bulan dengan perlakuan penambahan ekstrak air dan etanol rata-rata lama retensi menurun 36 detik dan 53detik mampu meningkatkan memori daya ingat dibandingkan kontrol. Sedangkan pada mencit umur 9 bulan meningkat dengan rata-rata lama retensi 38detik sampai 71detik tidak meningkatkan fungsi memori secara bermakna. Jika lama retensi mencit menunjukkan waktu lama pada saat terjadinya proses belajar dan mengingat mencit yang berlangsung pada neurotransmisi kolinergik maka pada penambahan ekstrak campuran (air dan etanol) lada hitam pada mencit umur 7 bulan juga dapat terlihat bahwa terjadinya peningkatan lama retensi yang baik dengan adanya penambahan dosis pada ekstrak lada hitam dibanding kontrol dimana rata-rata lama retensi 133detik, dan terjadi penurunan pada mencit umur 9 bulan dengan lama retensi 83 detik yang mampu meningkatkan fungsi kognitif dibandingkan dengan kontrol.

Perbandingan rata-rata waktu (detik) uji labirin mencit umur 7 bulan dan umur 9 bulan antara kelompok perlakuan menunjukkan adanya beda nyata antara rata-rata waktu (detik) kelompok kontrol dengan kelompok pemberian ekstrak lada hitam. 
Hasil penelitian membuktikan bahwa pengaruh ekstrak lada hitam dengan perlakuan ekstrak air, ekstrak etanol dan ekstrak campuran (air dan etanol) dapatmemberikan hasil yang baik pada fungsi kognitif mencit. Hal ini dikarenakan efek oksidan dari ekstrak lada hitam yang terkandung didalamnya lebih banyak dan dapat disebabkan karena meningkatnya kapasitas oksigen dalam kerja sel saraf mampu meningkatkan dan mampu menghasilkan respon gerak yang lebih baik. Dengan pemberian antioksidan dari ekstrak lada hitam diharapkan dapat memberikan pengaruh positif pada fungsi kognitif mencit. Kandungan lada hitam selain sebagai antioksidan juga memiliki kandungan senyawa fenol. Rachmi melaporkan bahwa ekstrak daun M.oleifera mengandung gugus fenol yang mempunyai efek protektif dari oksidatif. Shidharaju dan Beker juga melaporkan bahwa senyawa bioaktif yang utama pada gugus fenol masih merupakan golongan flavonoid.

Menurut Gupta (2003), Centella asiatica (L.) Urban dapatmeningkatkan fungsi kognitif dan oksidatif stressyang diinduksi dengan streptozotocin secara intracerebroventricular pada tikus dengan penyakit Alzheimer. Centella asiatica (L.) Urban juga dapat meningkatkan fungsi kognitif dan oksidatif stress pada tikus normal. Ekstrak cair Centella asiatica (L.) Urban yang meningkatkan fungsi kognitif pada dosis 200 $\mathrm{mg} / \mathrm{kg}$ BB dan $300 \mathrm{mg} / \mathrm{kg}$ BB.

\section{Uji Renang Mencit.}

Hasil perhitungan perbandingan rata-rata waktu (detik) tempuh mencit, antara mencit umur muda ( 7 bulan) dan mencit umur tua (9 bulan) disajikan dalam (Tabel 2).

Tabel 2. Perbandingan rata-rata (detik) tempuh renang mencit jantan antara kelompok umur 7 dan 9 bulan.

\begin{tabular}{cccc}
\hline No & Perlakuan & \multicolumn{2}{c}{ Waktu (detik) \pm SD } \\
\cline { 3 - 4 } & & 7 bulan & 9 bulan \\
\hline 1 & $\mathrm{~K}$ & $12,12 \pm 9,10 \mathrm{a}$ & $6,76 \pm 4,61 \mathrm{a}$ \\
2 & $\mathrm{C}$ & $14,16 \pm 19,06 \mathrm{a}$ & $5,48 \pm 2,95 \mathrm{a}$ \\
3 & $\mathrm{E}$ & $4,96 \pm 2,52 \mathrm{a}$ & $3,8 \pm 0,80 \mathrm{a}$ \\
4 & $\mathrm{~A}$ & $8,2 \pm 6,21 \mathrm{a}$ & $2,7 \pm 1,65 \mathrm{a}$ \\
\hline \multicolumn{3}{|c}{ Keterangan : Nilai yang diikuti pada huruf yang sama tidak } \\
\multicolumn{4}{c}{ berbeda nyata pada uji BNT dengan taraf } \\
& signifikans 5\%; (K) Kontrol, (C) Ekstrak \\
\multicolumn{4}{c}{ Campuran (Air dan Etanol), (E) Ekstrak } \\
Etanol, dan (A) Ekstrak Air.
\end{tabular}

Perlakuan ekstrak air lada hitam pada mencit umur 7 bulan rata-rata lama retensi 8 ,2detik tidak mampu meningkatkan kemampuan kognitif mencit, pada mencit umur 9 bulan ratarata lama retensi menurun 2,7 detik mampu meningkatkan fungsi kognitif. Sedangkan pada perlakuan ekstrak etanol lada hitam mencit umur 7 bulan lama rata-rata retensi 4,9 detik, pada mencit umur 9 bulan lam rata-rata retensi
3,8 detik. Pada mencit perlakuan ekstrak campuran (air dan etanol) lada hitam umur 7 bulan lama rata-rata retensi nya 4,16 detik dan pada mencit umur 9 bulan lama rata-rata retensi mencapai 5, 48 detik.

Hasil uji statistik ANARA, menunjukkan adanya beda nyata pada lama rata-rata retensi mencit. perbandingan rata-rata (waktu) renang mencit umur 7 bulan terdapat adanya beda nyata pada perlakuan ekstrak campuran. Sedangkan pada perbandingan mencit umur 9 bulan hanya pada ekstrak air yang terlihat adanya beda nyata. $\mathrm{Hal}$ ini disebabkan karena meningkatnya kapasitas oksigen dalam kerja sel saraf mampu meningkatkan dan mampu menghasilkan respon gerak yang lebih baik. Respon berupa gerak karena telah mengingat dan menemukan kembali jalan keluar labirin atau balok pijakan dalam air uji renang juga akan meningkat sehingga waktu untuk menyelesaikan uji labirin dan uji renang menjadi lebih cepat.

Menurut soewolo (2005) dengan meningkatnya daya ingat mencit juga dapat disebabkan semakin baiknya metabolisme tubuh sehubungan dengan meningkatnya kada hemoglobin darah yang banyak mengandung $\mathrm{O}_{2}$. Meningkatnya kapasitas oksigen maka kerja sel saraf meningkat dan dapat menghasilkan respon gerak yang lebih baik. Buzan (2003) menyatakan bahwa oksigen adalah sumber energi utama otak. Kemampuan kognitif pada mencit tua yang semakin menurun fungsi kognitifnya, akibat umur yang semakin tua sehingga daya ingat nya dapat berkurang. Secara fisiologi ingatan merupakan hasil dari perubahan kemampuan penjalaran sinaptik dari suatu neuron ke neuron berikutnya. Ingatan dibagi menjadi tiga yaitu ingatan jangka panjang, ingatan jangka pendek, dan ingatan jangka menengah. Faktor yang menyebabkan menurunnya ingatan antara lain kurang tidur, tekanan darah tinggi, terlalu banyak mengkonsumsi alkohol, stres kronis, dan kerusakan dalam hubungan sel saraf otak. Proses dalam belajar juga sangat penting sebab, dengan belajar semua sel-sel otak akan ikut aktif sehingga proses memori menjadi lebih mudah mengingat (Venustri, 2006).

\section{SIMPULAN}

Dari hasil penelitian dapat disimpulkan bahwa :

1. Mencit umur 9 bulan cendrung mengingat jalur dalam uji labirin dengan lama retensi 151 detik, tetapi cendrung tidak berbeda dengan mencit umur 7 bulan dalam mengingat balok pijakan pada uji renang dengan lama retensi 12,12 detik. 
2. Melalui uji labirin daya ingat mencit umur 7 bulan dan mencit umur 9 bulan yang diberi ekstrak lada hitam terbukti lebih baik dari pada yang tidak diberi ekstrak.

3. Dalam uji renang daya ingat mencit umur 7 bulan lebihbaik pada yang diberi ekstrak campuran dengan lama retensi 14,16 detik, dan pada mencit umur 9 bulan hanya ekstrak air yang bisa membuat daya ingat lebih baik dengan lama retensi 2,7 detik.

\section{DAFTAR PUSTAKA}

Buzan. 2003. Head Strong. Jakarta. PT Gramedia.

Gupta. 2003. Pengaruh Triterpen Total Pegagan (Centella asiatica(L)Urban) Terhadap Fungsi Kognitif Belajar dan Mengingat pada Mencit Jantan Albino(Mus musculus). Jurnal Penelitian Sains. Universitas Sriwijaya.

Hernani, M dan Raharjo. 2005. Tanaman berkhasiat Antioksidan. Penebar Swadya. Jakarta.

Ivey, A E. 1993. Conseling and Psychotherapy A Multicultural Perspective. Boston: Allyn and Bacon a Division of Simon and Schuster, Inc.

Majeed dan Prakash, L. 2000. The Medicinal Uses of Pepper. International Pepper News.Vol. XXV, No. 1 Jan-Mar 2000: 2331.
Meghwal M and Goswami TK. 2012. Nutritional Constituent of Black Pepper as Medicinal Molecules: A Review. 1: 129. doi:10.4172/scientificreports.12.

Rachmi E. Pengaruh Antioksidan dari Ekstrak Daun M. oleifera Terhadap Hepatotoksisitas CCL4. (Tesis). Universitas Brawijaya, Malang. 2004.

Shidharaju and Beker. Oxidative Stress In The Progression Of Alzheimer Disease In The Frontal Cortex. Neurologi. 2010; 69(2):155-167.

Singh R, Singh N, Saini BS, \& Rao HS. 2008. In vitro antioxidant activity of pet ether extract of black pepper. Indian J Pharmacol. Aug. 2008. Vol.40. Issue 4:147-151.

Soewolo . 2005. Fisiologi Manusia.Malang . Penerbit Universitas Negri Malang (UM PRESS).

Tahir, I., Wijaya, K., Widianingsih, D., (2003). Seminar on Chemometrics Chemistry Dept Gadjah Mada University,. Terapan Analisis Hansch Untuk Aktivitas Antioksidan senyawa Turunan Flavon/Flavonol. 25 Januari.

Venustri, L. 2006. Cara Memori Bekerja. http://www.pikiran-rakyat.com/cetak/2006. 2 Agustus 2009. 